\title{
RETÓRICA E MEMÓRIA EM ALGUMAS ESTROFES D’OS LUSÍADAS
}

\author{
Lourival da Silva Burlamaqui Neto ${ }^{1}$
}

\begin{abstract}
RESUMO: Nas sociedades de corte, o poema épico possuía íntima conexão com o discurso historiográfico. Nesses contextos, o enredo da ficção épica era construído sobre um notável feito da história nacional, cabendo ao escritor reconfigurar esse evento na trama poemática (dispositio) e ornálo com diversos recursos retóricos (elocutio). Dessa forma, a memória dos feitos nacionais e de outras ações louváveis do passado, à medida que constituía uma espécie de arquivo ao qual o autor recorria com o intuito de encontrar a matéria ideal para seu canto, também servia de parâmetro ao leitor que, averiguando as modificações e acréscimos impostos ao episódio histórico, avaliava a capacidade inventiva do poeta. Os Lusíadas, poema épico de Luís de Camões, insere-se nessa dinâmica e apresenta um notável aproveitamento das crônicas portuguesas medievais e dos relatos de viagem lusitanos, constituindo-se no panteão em que estavam presentes tipos históricos ilustres. $\mathrm{O}$ autor português, porém, considerando os preceitos de uma poética estruturada sobre Aristóteles (1984), Horácio (1984) e Quintiliano $(2015,2016)$ imprimiu variações nas suas fontes, articulando a memória dos feitos nacionais com um tratamento retórico engenhoso. Este artigo analisa algumas estrofes presentes nos cantos III e V de Os Lusíadas à luz do conceito memória e do teor retórico dessas passagens. Empregase a primeira definição para demonstrar que várias passagens do poema acumulam referências a textos de épocas diversas, aglutinando, em poucos versos, tempos muito distintos. Demonstra-se, assim, que a memória, além de ser um arcabouço de referências simbólicas, é o fio, a faculdade criadora que viabiliza esse amálgama temporal de imagens anacrônicas. Esse caleidoscópio temporal, como demonstram Alves (2011), Ford (2007) e Hansen (2008), possuía correspondência com a própria estrutura da epopeia, caracterizada pela heterogeneidade de gêneros retóricos. Por fim, trata-se brevemente, através do episódio do Adamastor, do esquecimento no panorama renascentista.
\end{abstract}

Palavras-chave: Os Lusíadas. Memória. Retórica.

\section{RETHORIC AND MEMORY AT SOME STANZAS OF THE LUSIADS}

ABSTRACT: On court society, the epic poem had a connexion with the historiographic discourse. On this context, the plot of epic fiction was constructed about a great action of national history. So, the writer should reconfigure this event on the fictional plot (Dispositio) and adorn the text with rhetoric resources (Elocutio). In this way, the memory of national events and of others great actions of the past constitute a kind of archive to which the author resort to find an ideal subject to her poem. This actions were a parameter to the reader evaluate the inventive ability of the poetry. Os Lusíadas, epic poem of Luís de Camões, it's inserted in this dynamic and presents a great exploitation of Portuguese chronics and travel reports, constituting the pantheon where the illustrious historical characters. The Portuguese author, however, considering the principles of a poetic structured on Aristotle (1984), Horace (1984) and Quintilian (2015, 2016), imprint variations in their sources, articulating the memory of national subject with a wit rhetorical treatment. This work analyses some stanzas of cantos III and V, using the concept of memory. We use this definition to demonstrate who various passages accumulate references to different times. We demonstrate who the memory isn't a framework of symbolic references, but a line, a creativity capacity who make feasible this amalgam of anachronistic images. This temporal kaleidoscope, as demonstrated by Alves (2011), Ford (2007) and Hansen (2008), had correspondence with the epic structure, characterized by the heterogeneity of rhetorical genres. By the end, we fought, through the Adamastor episode, about the forgetfulness during the renaissance.

\footnotetext{
${ }^{1}$ Doutorando em Teoria da Literatura pela Universidade Federal de Pernambuco (UFPE).
} 
Keywords: The Lusiads. Memory. Rethoric.

\section{Memória: o fio de Ariadne no amálgama temporal do texto épico}

Luís de Oliveira e Silva (2003), dissertando sobre as peculiaridades do gênero épico, propôs uma classificação para tais textos. Segundo o autor, no mundo homérico a guerra era uma situação corriqueira que, concedida aos homens pelos deuses, devia ser aceita. Embora dolorosos, o guerreiro podia extrair desses episódios, o louvor que faria seu nome ressoar nos tempos futuros. Assim, nessas ocasiões que lhe foram impostas, não cabia o perdão ou a fuga do campo de batalha. Pelo contrário, em sinal de respeito por aquele a quem daria glória, ou de quem iria recebê-la, os oponentes, antes da pugna, apresentavam seus nomes e suas genealogias. No épico de Virgílio, por sua vez, buscava-se uma justificativa para conflitos que não eram dignos de memória per si. As batalhas eram necessárias para que a grandeza de Roma se efetivasse. Assim, havia na Eneida (2014) uma assimetria entre a bie (a violência) e a dike (a justiça), ou seja, as personagens tinham consciência de que o assassínio era condenável, sendo tolerantes com os adversários se estes se submetessem ao domínio e aos valores romanos. Segundo Luís de Oliveira, o padrão virgiliano foi o modelo adotado nos poemas épicos do renascimento. Tais textos, reverberando a prática expansionista, não tratavam as batalhas como atos de valor imanente, considerando-as ações inevitáveis à dilatação de um império e de uma prática religiosa que, posteriormente, as redimiria.

Essa classificação do autor tem o mérito de apresentar padrões distintos de heroísmo para as epopeias. Um, associado à organização comunitária em tribos, que vislumbrava as batalhas como a régua que media o valor e as qualidades humanas. Outro, vinculado à organização estatal, que enxergava a vitória nos combates como pressuposto a uma realização maior: a edificação de um império e um tempo vindouro de paz e bonança, seguindo o modelo da pax romana.

Hélio Alves (2011) lança sobre as epopeias um olhar distinto da taxonomia de Luís de Oliveira. Concedendo maior relevância aos textos de matriz virgiliana, o autor lhes investiga as particularidades retóricas, corroborando a opinião de Luís de Oliveira acerca da ideologia que tais textos carregavam. As posições políticas, entretanto, segundo Alves, não estavam presentes apenas no conteúdo dos textos, mas principalmente na estrutura dessas 
obras. Compostos para membros das classes senhoriais, veja-se o exemplo da Eneida encomendada por Augusto, os poemas épicos fundiam elementos do gênero epidítico, empregue para fins laudatórios, comovendo a audiência através da amplificação de feitos, e do gênero deliberativo, utilizado nas ocasiões em que a argumentação para fins políticos se fazia necessária.

Segundo Alves, do primeiro gênero, o épico renascentista colheu o teor encomiástico, a natureza apostrófica, os longos catálogos que enumeravam feitos e o emprego dos símiles². Da segunda modalidade, por sua vez, retirou as partes do discurso ${ }^{3}$, trasladadas em etapas para a composição do texto. Associado a esses dois núcleos, estava o recurso da imitatio, utilizado pelo poeta para acumular na estrutura de seu texto a prática de várias modalidades textuais ${ }^{4}$. Por exemplo, Virgílio dispôs na Eneida o exercício de algumas tipologias de escrita como a história romana, ao pôr no livro VIII a descrição da batalha do Áccio e os livros sibilinos, ao narrar a descida de Eneias ao Hades no livro VI. Assim, reverberando a doutrina do mythos de Aristóteles e a imitatio latina, Hélio Alves considera o poema épico uma aglutinação de tradições poéticas, topos retóricos e doutrinas filosóficas que se materializavam no poema sob a forma de episódios. Os eventos eram dispostos no decorrer da trama de modo que a unidade da narrativa e o encadeamento das ações não fossem desfeitos.

Essa aglutinação de tradições retóricas também constitui um amálgama de tempos diversos. Veja-se, por exemplo, a seguinte passagem de Os Lusíadas:

Passamos a grande Ilha da Madeira, Que do muito arvoredo assi[m] se chama; Das que nós povoamos a primeira, Mais célebre por nome que por fama. Mas, nem por ser do mundo a derradeira, Se lhe avantajam quantas Vénus ama;

\footnotetext{
${ }^{2}$ Comparações de forte teor imagético. Nas epopeias de Homero, os símiles sempre associam o mundo dos deuses com um fenômeno cotidiano. Veja-se o exemplo: "Tal como quando o Noto derrama nos cumes das montanhas/ a bruma que aos pastores não agrada, mas que ao ladrão/ é mais propícia que a noite, pois apenas se consegue ver/ a distância do arremesso de uma pedra -/ assim se levantou um turbilhão de pó sob os pés/ dos que marchavam; e depressa atravessaram a planície" (HOMERO, 2014, p.162)

3 As partes do discurso, dependendo da fonte consultada, mudam. Aristóteles (2012) apresentou quatro partes: I) o proêmio, correspondente à proposição épica; II) a narração; III) as provas; IV) o epílogo.

${ }^{4}$ Quintiliano, na sua Instituição Oratória, observava a importância da imitatio para a aprendizagem dos ornamentos poéticos e da melhor disposição para o enredo: “[...] deve-se voltar a mente para os exemplos de todas as boas qualidades aí encontradas. Pois não resta dúvida de que grande parte da arte se baseia na imitação. Como criar foi e continua a ser o primeiro intento, do mesmo modo é útil acompanhar o que foi bem estabelecido." (Quintiliano, 2016, p. 85)
} 


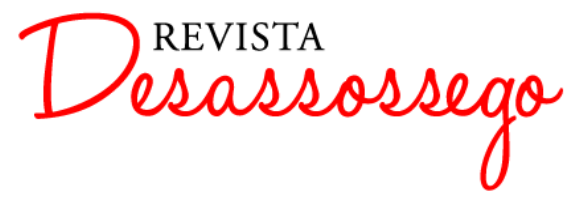

DESASSOSSEGO 20 | DEZ/2018 | ISSN 2175-3180

Antes, sendo esta sua, se esquecera

De Cipro, Gnido, Pafos e Citera.

(CAMÕES, 2008, p. 116)

A estrofe pode ser subdividida em duas grandes partes. A primeira corresponde aos quatro versos iniciais, a segunda, aos quatro últimos. As duas partes possuem funções distintas, pois, enquanto as linhas poéticas iniciais fornecem a localização da esquadra lusitana no itinerário da viagem, os versos finais são um comentário erudito sobre o logradouro. Os primeiros versos, referentes à ilha da Madeira, possuem semelhanças com a descrição que o historiador João de Barros fez da ínsula:

João Gonçalves, e Tristão Vaz [...] determinaram de ir ver se era terra huma grande sombra que lhe fazia a Ilha, a que ora chamamos da Madeira, na qual havia muitos dias que se não determinavam, porque por razão da grande humidade que em si continha com a espessura do arvoredo, sempre a viam afumada daquelles vapores [...]. Assi que movidos deste desejo, em dous barcos que fizeram da madeira da ilha que estavam, vendo o mar pera isso disposto, passaram-se a ella, á qual chamaram da Madeira por causa do grande, e mui espesso arvoredo de que era cuberta. Nome já mui celebrado, e sabido per toda a nossa Europa, e assi em muitas partes de Africa, e Asia [...] (BARROS, 1778, p. 29-30, grifo nosso)

O historiador, assim como Camões, mencionou a origem do topônimo e também afirmou que, embora a ilha não possuísse uma nuance específica que lhe concedesse fama, seu nome, ou seja, a notícia de sua existência já era bem disseminada. Essas afinidades entre os dois textos autorizam a hipótese, já apresentada por José Maria Rodrigues (2010, p. 152), de que esse texto histórico foi a fonte da referida passagem do texto camoniano.

Nos quatro versos finais da estância, há uma comparação entre a ínsula descoberta pelos portugueses e algumas ilhas (Cipro, Gnido, Pafos, Citera) nas quais, durante a antiguidade, existiam templos dedicados à deusa Vênus. Todas as menções geográficas foram colhidas por Camões na obra de autores gregos como Homero. Veja-se, como exemplo, essa passagem da Odisseia na qual alguns dos locais referidos pelo narrador são mencionados: "Mas para Chipre se dirigiu Afrodite, deusa dos sorrisos;/ foi para Pafos, pois aí tem seu templo e seu perfumado altar" (HOMERO, 2014, p. 249, grifo nosso). Esses topônimos também eram frequentes em escritores da lírica erótica romana como Catulo: "Então, deusa do mar azul nascida, que/ [...] Cnido rico em canas habitas [...]” (CATULO, 1996, p. 92, grifo nosso). 
Dessa forma, se a primeira parte da estrofe provinha do conhecimento das narrativas historiográficas portuguesas, o segundo trecho era oriundo das leituras de poesia antiga. Têm-se, assim, na mesma passagem, a presença de tradições textuais distintas e uma conjunção de tempos heterogêneos: uma temporalidade associada à antiguidade e outra ligada às grandes navegações. O fio que amarrava os variados tempos era a memória e uma consequência desse amálgama temporal foi a fusão entre res ficta e res facta, ou seja, entre traços fictícios e fatos históricos.

Tal processo concedia uma dimensão histórica ao mito (as narrativas de Vênus) ao mesmo tempo em que mitificava um evento histórico (a viagem às Índias). Desse modo, a referência à mitologia deixava de ser mero adorno estético, tornando-se presentificação mnemônica ${ }^{5}$ e a própria noção de tempo cronológico também era posta em cheque. A continuidade se transformava em simultaneidade e o passado se tornava presente. Assim, Camões não contemplava integralmente a antiguidade, mas recordava alguns de seus dados, à medida que esquecia outros, aproveitando-os em seu projeto de mitificação dos feitos lusitanos numa época em que o apogeu de Portugal já dava claros sinais de ter chegado ao fim . Recorde-se a célebre passagem de Walter Benjamin (2016, p.11): “Articular historicamente o passado não significa reconhecê-lo 'tal como ele foi'. Significa apoderarmonos de uma recordação (Erinnerung) quando ela surge como um clarão num momento de perigo".

Outra passagem que ilustra uma aglutinação temporal semelhante é a estrofe VII do canto quinto:

\footnotetext{
${ }^{5}$ Essa presentificação mnemônica estava ligada também à constituição de uma tradição. Ou seja, Camões poderia mencionar no seu épico várias informações do período. O que o levou a recordar algumas, aproveitando-as no texto foi a afinidade entre essas e seu projeto poético. Por exemplo, Vênus era a divindade protetora de Eneias, protagonista da Eneida, épico admirado pelo autor português. Logo, citá-la estabelecia um vínculo constitutivo de uma genealogia. Essa filiação, porém, também estava lado a lado com o desejo de superação e atribuição de valor à ilha da Madeira. Considerá-la superior às antigas era sugerir que os feitos portugueses iriam superar as façanhas da antiguidade, tornando a matéria d'Os Lusíadas mais nobre.

${ }^{6} \mathrm{Na}$ segunda metade do século XVI, Portugal já administrava com certa dificuldade as praças do oriente. Nos excursos dos cantos VI e VII, essa dificuldade ressoa n'Os Lusíadas. O narrador do poema tece críticas aos administradores de além-mar, acusando-os de colocarem os próprios apetites sobre o bem comum. Para além dessas ingerências administrativas, havia o problema da sucessão real. Durante as regências de D. Catarina e do cardeal D. Henrique, muitos esforços foram feitos para a manutenção e defesa das terras já conquistadas. Durante a ascensão de D. Sebastião ao trono, os esforços se voltaram à conquista de Marrocos, tratando-se as demais praças e o próprio reino com descuido. O tratado Da ensinança e educação do rei, escrito por D. Jerônimo Osório (2005), apresenta muitos dos equívocos praticados pelo jovem monarca. Eduardo Lourenço (1999, p. 19) observa como a imagem imperial do reino mascarou aspectos da realidade política, favorecendo, pouco a pouco, seu declínio: "O Império-refúgio tinha-se tornado, com o tempo, um refúgio ilusório e fizera perder ao pequeno país que o inventara o sentido das realidades."
} 
Passamos o limite aonde chega

O sol, que pera o Norte os carros guia;

Onde jazem os povos a quem nega

O filho de Climene a cor do dia.

Aqui gentes estranhas lava e rega

Do negro Sanagá a corrente fria,

Onde o Cabo Arsinário o nome perde,

Chamando-se dos nossos Cabo Verde.

(CAMÕES, 2008, p. 116)

Este passo expõe a passagem da frota lusitana pelo trópico de Câncer. Essa linha imaginária é apresentada pelo capitão como a fronteira entre o norte da África, região habitada pelos africanos mouros e brancos, e a África subsaariana povoada pelos negros. A narração da entrada no território austral, utiliza um mito presente nas Metamorfoses de Ovídio para justificar a tez escura dos habitantes dessa região. Segundo o relato ovidiano, Faetonte, filho de Hélio (Sol), ao tentar dirigir o carro do pai, perdeu o controle da direção, incendiando vastas extensões terrestres. Após serem queimados, os povos vitimados pelo acidente teriam adquirido a cútis negra. Ao término da referência ao episódio mitológico, o capitão-mor continua sua exposição, relatando a passagem da esquadra pelo rio Senegal e a chegada ao Cabo Verde. Por fim, Vasco da Gama observa que os portugueses renomearam essa última região que, antes de suas chegadas, possuía uma denominação ptolomaica. As semelhanças entre a estrofe e outra passagem das Décadas, obra do historiador português João de Barros, são flagrantes:

\footnotetext{
A terra, que jaz entre estes dous rios, faz hum notável cabo, a que os nossos chamam Verde, e Ptholomeu Arsinario promontório; e posto que ele o situe em largura de dez gráos, e dous terços, e per nós seja verificado em quatorze e hum terço [...] não pode ser outro. E tambem por ficar entre dous notaveis rios, a que elle chama Darago, que he Çanagá, e Stachires Gambea [...] E esse rio Çanagá per a divisão nossa he o que aparta a terra dos Mouros dos Negros, posto que ao longo de suas aguas todos são mestiços, em cor, vida, e costumes [...] (BARROS, 1778, p. 217 - 219, grifo nosso)
}

A utilização desse texto histórico como uma das fontes para a estância possui os seguintes objetivos: A) Informar; B) O manuseio engenhoso de uma matéria coletiva. 
Matos (2011, p. 506), examinando o caráter bilateral das navegações portuguesas, afirma que os empreendimentos provinham de um conhecimento acumulado que, em contrapartida, acabava originando novos saberes. As informações sobre povos e regiões desconhecidas, obtidas durante as viagens, eram registradas pelos cronistas. Assim, Camões, ao utilizar esses textos históricos para compor passagens de seu épico, concedeu-lhe realismo e uma dimensão cognitiva, proveniente desse teor livresco.

Quanto ao segundo propósito é importante observar na estrofe como Camões manuseava o material histórico que tinha à sua disposição. O poeta o ajustava aos moldes da oitava-rima, do decassílabo heroico e ao esquema rímico abababcc. A passagem dos trechos colhidos em João de Barros para a menção mitológica também é engenhosa, ocorrendo sem cortes abruptos, permitindo a variação das narrativas que serviram de fonte para o escritor português. O amoldamento formal e esse desvio de conteúdo, ao promoverem uma reorganização de matérias coletivas, descortinavam a perícia verbal do escritor, permitindo a avaliação de seu texto pelos receptores coevos. Hansen (2008, p. 41), a respeito dessa flexibilidade, afirma:

Como toda verossimilhança, o verossímil épico é um efeito de adequação produzido pelo destinatário quando relaciona o discurso do poema com discursos de gênero histórico. A forma da poesia épica - ficção em estilo sublime de fábula composta de ações valorosas de personagens heroicos - deve ser semelhante à matéria da história - guerras históricas, feitos de homens históricos - mas não idêntica. Se o fosse, o poema não seria poesia, nem causaria prazer com a engenhosidade do artifício verossímil.

Assim, o poeta, colhendo as linhas mestras de seu relato na obra de João de Barros e em textos da antiguidade, além de dar origem a um caleidoscópio temporal, levou adiante a variação elocutiva de um material coletivo concedendo à memória social um tratamento retórico.

\section{2 Épico: a versificação da memória coletiva}

Ford (2007, p.106-107), chegando a resultados semelhantes aos de Alves (2011), afirmava que as duas epopeias de Homero eram compilações de narrativas menores. Esses enredos, segundo o autor, eram entoados na Grécia arcaica por uma classe específica de cantores: o aoidos. Dirigida a uma plateia, a história (oimê), declamada por tais cantores 


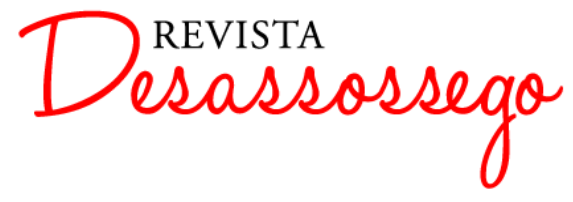

DESASSOSSEGO 20 | DEZ/2018 | ISSN 2175-3180

DOI: http://dx.doi.org/10.11606/issn.2175-3180.v10i20p5-21

itinerantes, não apresentava personagens coevos ao público que as escutava. Os indivíduos presentes nesses relatos eram tipos possuidores de um contato mais íntimo com os deuses e capazes de façanhas notáveis como, por exemplo, derrotar, com extrema facilidade, diversos soldados da frente inimiga e levantar objetos impossíveis de serem erguidos pelos demais ${ }^{7}$.

Para o helenista norte-americano somente após muito tempo os relatos foram, aos poucos, reunidos em uma trama coesa, ganhando uma versão escrita. Porém, mesmo com a nova forma, ainda era possível identificar resquícios de oralidade. Um indício é a presença de threnoi, melodias lutuosas, partheneion, cantos entoados por coros de donzelas, e molpé, melodias para bailar. Nos trechos em que aparecem, esses cânticos não são meros ornamentos enfeixados a uma trama medular, mas formas de expressão que exercem uma funcionalidade no enredo. Veja-se, por exemplo, a presença ostensiva de invocações. A invocação das mousas, divindades filhas de Zeus e Mnemosine, deusa da memória, sempre buscava atribuir ao conteúdo da narração um teor de veracidade. No canto II da Ilíada, por exemplo, o rogo que o aoidos dirige à deusa é acompanhado dos seguintes versos:

Dizei-me agora, ó Musas que no Olimpo tendes vossas moradas-

Pois sois deusas, estais presentes e todas as coisas sabeis, Ao passo que a nós chega apenas a fama e nada sabemos-, Quem foram os comandantes dos Dânaos e seus reis.

A multidão eu não seria capaz de enumerar ou nomear, Nem que tivesse dez línguas, ou então dez bocas, Uma voz indefectível e um coração de bronze, A não ser que vós, Musas Olímpias, filhas de Zeus detentor da égide Me lembrásseis todos quanto vieram para debaixo de Ílion. (HOMERO, 2014, p. 148)

Segundo Ford (2007, p. 109-111), na Grécia arcaica, a prática exaustiva da narração não era suficiente para distinguir o canto do aedo da palavra de um cantor qualquer, fazendo-se necessária a ajuda das musas. Quem prescindisse desse auxílio divino poderia entoar uma história, oimé, bela e harmônica, mas sua exposição seria considerada falaciosa, pois o público do período atribuía a essas narrações, além da dimensão estética, uma função sagrada.

João Adolfo Hansen (2008) aboliu classificações secundárias, postulando a existência de apenas um cânone épico. Para o autor, qualquer epopeia tem como princípio básico o

\footnotetext{
${ }^{7}$ No século IV, essas características da epopeia foram apresentadas por Aristóteles (1984) na sua Poética, primeira sistematização das formas literárias, como traços distintivos do gênero épico. Essa obra, popular durante o Renascimento, constituiu um dos pilares das reflexões sobre as letras no período.
} 


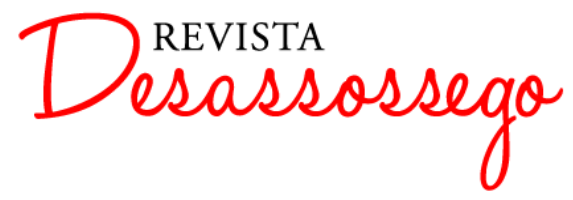

DESASSOSSEGO 20 | DEZ/2018 | ISSN 2175-3180

DOI: http://dx.doi.org/10.11606/issn.2175-3180.v10i20p5-21

epos, ou seja, a palavra, que mira a kleos, a fama, das res gestae, das coisas feitas, das ações notáveis. Lançando um olhar arquetípico sobre essas produções textuais, o crítico discerniu três paradigmas imanentes a essas narrativas: I) a soberania, presente na figura de um rei, de um chefe de tribo ou de um chefe religioso; II) a função guerreira, representada na imagem de um herói ou de uma classe responsável pela manutenção da segurança de um clã ou de um estado; III) a função econômica que tangencia os procedimentos técnicos, as decisões e as atividades capazes de levar uma comunidade a um longo período de prosperidade. Privilegiando o segundo paradigma, a função guerreira, como a mais importante na epopeia, o autor afirma que, em grande parte dos épicos, o conteúdo das batalhas é um material histórico de domínio coletivo, inserido na trama após receber uma variação elocutiva. Esse procedimento regozija o leitor consciente do artifício.

Por exemplo, no canto III de Os Lusíadas é apresentada a narrativa de Egas Moniz. Esse cortesão foi fiador de uma promessa que D. Afonso Henrique fez ao imperador Afonso VII de Castela e Leão. Como o monarca português não conseguiu honrar sua parte no acordo, Egas se apresentou com a família ao rei espanhol para quitar com a própria vida a dívida lusitana. Ocorrido no século XII, esse episódio se tonou bastante popular nos séculos seguintes. Uma comparação entre sua ocorrência no poema épico e sua aparição na obra de Duarte Galvão, historiador do século XV, mostra que, excetuando-se algumas pequenas variações, o conteúdo dos dois textos é o mesmo. As principais mudanças estão no plano da forma (a métrica, as rimas, as referências intertextuais):

Vindo o tempo do prazo em que o Príncipe D. Affonso Henrique havia de ir às cortes, que se faziam em Toledo. Segundo a menagem que D. Egas fizera a El Rei de Castella, ordenou-se D. Egas de todo, e partio com sua molher, e filhos, e chegaram a Toledo, foram descer ao Paço onde El-Rei estava, e ali se despiram de todolos panos senão os de linho, e sua molher com um pelote mui ligeiro, trajo daquele tempo, descalçaram-se todos, e pozeram senhos baraços nos pescoços, e assi entraram pelo Paço onde ElRei estava com muitos Fidalgos [...]. - Senhor me venho presentar ante vós, e eis aqui estas mãos com que vos fiz a menagem, e a língua com que vo-la disse, e demais vos trago aqui minha molher, e estes moços meus filhos para se vossa ira houver por maior minha culpa que a vingança do meu corpo só, por esta molher, e por estes moços a cuja fraqueza, e idade, a ira dos imigos soe apiedar-se, seja vossa indinação satisfeita [...]. Desde D. Egas acabou de falar ficou El-rei mui irado, e quizera mandar mandalo matar, dizendo que o havia enganado, mas os fidalgos que ahi estavam lhe disseram, que tal não fizesse, que não tinha rezão de lhe fazer nhum mal, porque D. Egas fizera todo seu dever como mui nobre, e leal vassalo [...]. (GALVÃO, 1906, p. 58-59) 


\section{XXXVII}

Chegado tinha o prazo prometido, Em que o Rei Castelhano já aguardava

Que o Príncipe, a seu mando so[b]metido, Lhe desse a obediência que esperava.

Vendo Egas que ficava fementido,

O que dele Castela não cuidava,

Determina de dar a doce vida

A troco da palavra mal cumprida.

\section{XXXVIII}

E com seus filhos e mulher se parte

A alevantar co eles a fiança,

Descalços e despidos, de tal arte

Que mais move a piedade que a vingança.

- Se pretendes, Rei alto, de vingar-te

De minha temerária confiança,

Dizia, eis aqui venho oferecido

A te pagar coa vida o prometido.

\section{XXXIX}

Vês aqui trago as vidas inocentes

Dos filhos sem pecado e da consorte;

Se a peitos generosos e excelentes

Dos fracos satisfaz a fera morte.

Vês aqui as mãos e a língua delinquentes:

Nelas sós exprimenta toda sorte

De tormentos, de mortes, pelo estilo

De Sinis e do touro de Perilo.

\section{XL}

Qual diante do algoz o condenado,

Que já na vida a morte tem bebido,

Põe no cepo a garganta e, já entregado.

Espera pelo golpe tão temido:

Tal diante do Príncipe indi $[\mathrm{g}]$ nado

Egas estava, a tudo oferecido.

Mas o rei vendo a estranha lealdade,

Mais pôde, enfim, que a ira a piedade.

(CAMÕES, 2008, p. 68-69)

As modificações impostas pelo poeta à matéria concediam à poesia uma liberdade que a história não possuía, permitindo que o escritor demonstrasse seu engenho. $\mathrm{Na}$ ambiência renascentista, essa autonomia da ficção em relação à história estava ancorada nas 


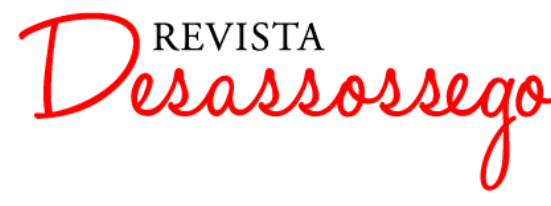

DESASSOSSEGO 20 | DEZ/2018 | ISSN 2175-3180

DOI: http://dx.doi.org/10.11606/issn.2175-3180.v10i20p5-21

reflexões de Aristóteles (1984) e Quintiliano (2015). O primeiro em conhecida passagem do tópico IX da Poética, afirmava que a poesia era mais universal que a história:

\begin{abstract}
Com efeito, não diferem o historiador e o poeta por escreverem verso ou prosa (pois que bem poderiam ser postos em verso as obras de Heródoto, e nem por isso deixariam de ser história, se fossem em verso o que eram em prosa) - diferem, sim, em que diz um as coisas que sucederam, e outro as que poderiam suceder. Por isso a poesia é algo de mais filosófico e mais sério do que a história, pois refere aquela principalmente o universal, e esta o particular. (ARISTÓTELES, 1984, p. 249)
\end{abstract}

O segundo, na Instituição Oratória, observava que a retórica não possuía compromisso com a verdade, mas com o verossímil: "Seguramente, o orador não anula o argumento apresentado por ele mesmo, como a retórica também não, porque entre os que consideram o convencer o objetivo dela, ou se alguém [...] confrontar casos entre dois homens bons, verá que buscam a verossimilhança.” (QUINTILIANO, 2015, p. 365). Nas poéticas renascentistas, essas passagens constituíam a base para as reflexões sobre a ficção. Hansen, levando em conta esses tratados e os textos antigos que lhe serviram de base, observa que, além de permitirem a avaliação da habilidade do escritor, as alterações deviam ser verossímeis, ou seja, deviam endossar as opiniões vigentes. Esse, então, era o principal papel do poema épico em tais comunidades: ser o panteão no qual estavam presentes tipos históricos ilustres que, possuindo suas ações amplificadas, deveriam servir de modelo para os cortesãos, incitando-os a atitudes semelhantes. Assim, a epopeia convertia-se em um arco que concatenava passado e futuro, louvando o primeiro à medida que pressupunha um segundo ainda mais grandioso.

Tanto Hansen (2008) quanto Ford (2007) realçam a dependência do texto épico da memória. Os dois, entretanto, ao justificarem a sujeição, não apontam como único motivo a nostalgia do passado, considerando também a expectativa pelo futuro. Agamben (2016) pondera que nossa imagem da posteridade está, frequentemente, ligada a um quadro messiânico, ou seja, a uma experiência futura que vai nos redimir do passado e do presente. Essa projeção redentora, segundo o filósofo italiano, se enraizou na cultura ocidental e passou a possuir íntima relação com as memórias dos grupos aos quais pertencemos: nação, religião, classe social, dentre outros. Ou seja, o homem quando vivencia a experiência da coletividade, recebe, sob a forma de uma trama, memórias coletivas. Esse enredo segue a 
dinâmica memória/esquecimento ${ }^{8}$ e pressupõe continuidade. A sequência da trama será escrita pelos novos partícipes de tais grupos, os quais farão projeções do tempo que virá. Esse ou será tão grandioso quanto o passado ou irá superá-lo, redimindo-o. Dessa forma, o texto épico, repositório de referências simbólicas (ações, tipos ilustres, episódios notáveis) que atribuíam sentido ao indivíduo que o lia, realizava um processo semelhante: trazia tipos do passado, inseria-os na dinâmica do presente e os propunha como modelos para alternativas e soluções futuras.

\section{Um excurso sobre o Adamastor e o esquecimento}

Segundo Erich Auerbach (2013), todo autor tem sua percepção de mundo modelada pelos valores e pelas práticas sociais vigentes no contexto social em que está inserido. Assim, ao compor uma obra, mesmo que indiretamente, o escritor traslada para o texto essa assimilação, historicamente orientada, do real e da história. Por exemplo, ao analisar um episódio da Canção de Rolando no qual Ganelão, um vassalo do imperador Carlos Magno, põe outro servo do monarca (Rolando) em situação vexatória e arriscada, Auerbach afirma que a incongruência entre a relevância do imperador e sua delicada condição de refém das desavenças de seus súditos estava associada com a débil condição central que o rei ocupava no sistema feudal durante o século XI, período em que a obra foi composta.

O filólogo também pondera que cada época possui nuances literárias próprias. Tais características podem ser discernidas com maior clareza no tratamento que um período dá à teoria dos estilos ${ }^{9}$, ou seja, é forçoso averiguar se um ínterim recusa ou acata essa hierarquização dos gêneros para se compreender de maneira profunda a produção literária

\footnotetext{
8 A narrativa (mythos) que o ser humano recebe quando está inserido em um determinado grupo social não abrange a totalidade dos eventos do passado, contendo apenas os episódios relevantes para o grupo em questão. Assim, um número considerável de acontecimentos é esquecido para que outros permaneçam na recordação. A retenção de todas as ocorrências do passado ocasionaria uma contemplação permanente das coisas, em vez de uma narrativa historiográfica. Didi-Huberman, a esse respeito, comenta: “[...] não é exatamente o passado que se constitui no objeto das disciplinas históricas porque não é exatamente uma ciência o que pratica o historiador. O primeiro ponto nos ajuda a compreender algo que depende de uma memória, quer dizer, de uma organização impura, de uma montagem [...] do tempo.” (HUBERMAN, 2000, p. 39, tradução nossa)

9 Teoria que predicava uma distinção rígida entre os estilos alto, mediano e baixo. Esta separação ortodoxa apregoava que as ações de membros das classes senhoriais deveriam ser apresentadas em molduras heroicas ou trágicas que pressupunham um acentuado pendor de estilização, enquanto a vida cotidiana de tipos modestos, necessariamente, seria exposta em caixilhos deformadores que, utilizando um estilo desconexo, lhes concedia uma dimensão burlesca e caricatural. No permeio desses extremos estaria a apresentação de episódios campesinos em estilo que, se não deformava, era humilde e buscava delinear cenas leves e aprazíveis.
} 
do intervalo de tempo em questão ${ }^{10}$. Por exemplo, Auerbach questionava porque a já referida canção de Rolando ao expor figuras reais o fazia em um estilo truncado, repleto de curtas orações coordenadas. $\mathrm{O}$ autor chega à conclusão de que na Idade Média a rígida distinção dos estilos foi, em parte, abolida porque, embora a maioria dos textos apresentasse apenas nobres e reis, essa representação ocorria em uma época de uniformização das formações, ou seja, os nobres e a populaça tinham acesso limitado a uma educação clássica. Assim, mesmo os textos, compostos por monarcas, em que figuravam tipos reais possuíam um estilo simples que era compreensível a todos.

Desse modo, para o crítico alemão, as múltiplas práticas sociais de povos distintos constituíam-se em filtros que circunscreveriam uma maneira particular de enxergar o real e a história. Logo, épocas e nações diferentes pressuporiam compreensões teleológicas e ontológicas próprias que, por si só, já bastariam à consumação de modelos peculiares de representação. Acrescente-se a isso arranjos voláteis dos gêneros literários que, articulados a estruturas hermenêuticas e sociopolíticas, podiam ser modificados sempre que estas sofriam abalos, realçando ainda mais a heterogeneidade das possibilidades de representação literária.

Neste artigo, recorre-se às ideias de Auerbach (2013) para se compreender que tipo de entrave o Adamastor representava aos portugueses. Ao contrário do que ocorria na Odisseia e na Eneida, onde Polifermo, Cila e as Harpias se opunham, respectivamente, à passagem das frotas de Odisseu e Eneias, causando-lhes muitos danos, Adamastor conta que já se insurgiu contra os portugueses que o atravessaram e profetiza agruras aos lusitanos. Porém, não os ataca, nem causa males à frota lusa. Outra nuance que merece destaque é a postura de Vasco da Gama ao se deparar com esse monstro. Se, para não precisar ser devorado pelo ciclope Polifermo, Odisseu precisou empregar sua astúcia, ou se, para não ter seus mantimentos extraviados pelas Harpias, Eneias travou um combate com esses monstros, o nauta português, ao encontrar Adamastor, além de lhe dirigir uma questão, apenas roga o auxílio divino para o superar, pedindo que as imprecações do monstro não se concretizem. Dessa forma, embora seja apresentado como um prodígio disforme, com a

\footnotetext{
10 As poéticas renascentistas, apoiando-se nos textos basilares de Aristóteles (1984) e Quintiliano (2016), endossaram essa tripartição. Os autores do período colheram na Poética a articulação entre a índole da personagem e a forma como ela é ficionalizada: "Pois a mesma diferença separa a tragédia da comédia; procura, esta, imitar os homens piores, e aquela, melhores do que eles ordinariamente são." (ARISTÓTELES, 1984, p. 242). Quintiliano, por seu turno, estabeleceu que a imitatio devia observar a separação dos gêneros: "Cada gênero literário tem sua própria lei e também sua própria beleza. Realmente, a comédia não se torna mais respeitável pelo uso dos coturnos da tragédia; ao contrário, a tragédia não se apresenta como calçado soco dos comediantes.” (QUINTILIANO, 2015, p. 97).
} 
mesma espontaneidade que surge, o gigante se vai e Vasco da Gama aparenta ser, no curso do episódio, mais interlocutor do que oponente.

Se o monstro não impede a passagem dos portugueses por que surge? Após sua aparição, por que Adamastor some, se a frota não esboça sequer um ataque? $\mathrm{O}$ monstrengo surge para encarecer a passagem de Vasco da Gama pelo cabo. A leitura dos relatos historiográficos coevos demonstra que a travessia do acidente geográfico pelas naus do Gama ocorreu sem maiores percalços. Entretanto, era preciso que o autor dramatizasse a transposição, tendo em vista que esse local foi durante anos o limite do mundo conhecido e motivo de preocupação para os nautas que temiam suas borrascas. Consequentemente, a estratégia textual que o autor empregou para amplificar as dificuldades dessa travessia foi a aparição dessa personagem. Mas se o nume surgiu para problematizar esse trepasse, por que não desferiu ao menos um golpe?

Se para a tradição épica renascentista a maior recompensa que um homem poderia receber por seus atos era a glória perene, o maior prejuízo seria o esquecimento. Assim, o monstrengo não se insurgiu contra os portugueses, lançando mão de socos e estocadas, mas com a promessa de que todos os seus esforços seriam vãos, visto que os nautas do futuro teriam o mesmo destino dos nautas do passado que, ao tentarem lhe atravessar, pereceram. Uma compreensão exitosa do tipo de entrave que o personagem representa para os portugueses pressupõe a exposição de passagens do primeiro discurso do Adamastor:

\section{XLI}

E disse: - Ó gente ousada, mais que quantas

No mundo cometeram grandes cousas, $\mathrm{Tu}$, que por guerras cruas, tais e tantas, E por trabalhos vãos nunca repousas, Pois os vedados términos quebrantas E navegar meus longos mares ousas, Que eu tanto tempo há já que guardo e tenho, Nunca arados de estranho ou próprio lenho;

\section{XLII}

Pois vens ver os segredos escondidos Da natureza e do úmido elemento, A nenhum grande humano concedidos De nobre ou de imortal merecimento, Ouve os danos de mi $[\mathrm{m}]$ que apercebidos Estão a teu sobejo atrevimento, Por todo o largo mar e pela terra 


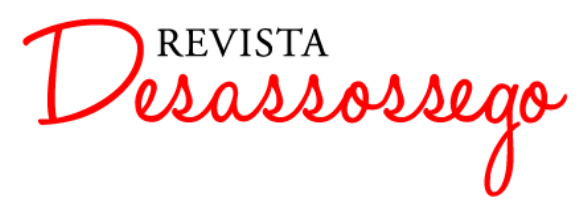

DESASSOSSEGO 20 | DEZ/2018 | ISSN 2175-3180

Que inda hás de so[b]jugar com dura guerra.

$[\ldots]$

\section{XLIV}

Aqui espero tomar, se não me engano, De quem me descobriu suma vingança.

E não se acabará só nisto o dano

De vossa pertinace confiança:

Antes, em vossas naus vereis, cada ano, Se é verdade o que meu juízo alcança,

Naufrágios, perdições de toda sorte, Que o menor mal de todos seja a morte! (CAMÕES, 2008, p. 123-124)

É curioso observar que nas duas estâncias iniciais do trecho, embora o discurso do monstro possua um tom de ameaça, ele guarda um elogio velado aos portugueses. Assim, antes de contar o que pretende fazer com aqueles que tentarem lhe cruzar, Adamastor se dirige aos lusitanos, intitulando-os gente ousada, ressaltando seu atrevimento, superior aos dos demais povos (estrofe 41), e suas incansáveis ações que visavam ultrapassar os limites conhecidos (estrofe 42). O monstro chega a prever que essa gente dominará os mares e as terras. Para a mentalidade renascentista, a superação das fronteiras implicava, além dos benefícios materiais, atitudes que, análogas às ações dos antigos, concederiam a seus agentes uma fama que jamais seria apagada. Por isso, mais adiante, ao ponderar o mal que irá impor aos portugueses, o monstrengo afirma: "Naufrágios, perdições de toda sorte,/ Que o menor mal de todos seja a morte!" (CAMÕES, 2008, p. 124).

Como se verificou durante a exposição da mímesis para Erich Auerbach, épocas distintas possuem percepções distintas do real e da história. Logo, se para a tradição épica renascentista a maior recompensa que um homem poderia receber por seus atos era a glória perene, nesse excerto, o mal maior que a morte corresponde ao esquecimento que encobrirá as fracassadas ações dos lusos, apagando-as da história. Dessa forma, o Adamastor se insurgiu contra a frota de Vasco da Gama, mas, sendo o antagonista de um épico do Renascimento, ao invés de fazer uso da força, lançou mão da palavra, prometendo o silencio para as façanhas dos nautas.

\section{REFERÊNCIAS}




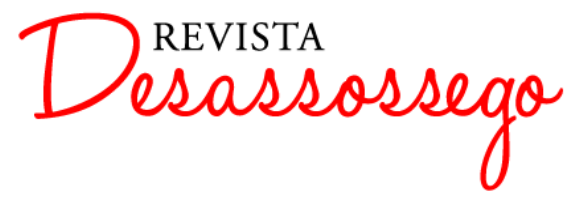

DESASSOSSEGO 20 | DEZ/2018 | ISSN 2175-3180 DOI: http://dx.doi.org/10.11606/issn.2175-3180.v10i20p5-21

AGAMBEN, Giorgio. O tempo que resta: um comentário à Carta aos Romanos. Belo Horizonte: Autêntica Editora, 2016.

ALVES, Hélio. Épica na Literatura Portuguesa do século XVI. In: SILVA, Vítor Aguiar e (coord.). Dicionário de Luís de Camões. São Paulo: Leya, 2011.

ARISTÓTELES. Poética. Tradução: Eudoro de Souza. In: PESANHA, José Américo Motta. Aristóteles. São Paulo: Nova Cultural, 1984. (Os Pensadores).

ARISTÓTELES. Retórica. São Paulo: Editora WMF, Martins Fontes, 2012.

AUERBACH, Erich. Mimesis: a representação da realidade na literatura ocidental. 6. ed. São Paulo: Perspectiva, 2013.

BARROS, João de; COUTO, Diogo de. Da Asia. Lisboa: Regia Officina Typografica, 1778. Disponível em: HTTPS://archive.org/stream/daasiadejoodeb00barr\#page/n7/mode/2up. Acessado em: Maio de 2015.

BENJAMIN, Walter. O anjo da história. 2. ed. Belo Horizonte: Autêntica Editora, 2016. CAMÕES, Luís de. Obra Completa. Organização, introdução, comentários e anotações de Antônio Salgado Junior. Rio de Janeiro: Nova Aguilar, 2008. (Biblioteca Luso-Brasileira. Série Portuguesa).

CATULO. O livro de Catulo. Tradução, introdução e notas de João Ângelo Oliva Neto. São Paulo: Edusp, 1996.

DIDI-HUBERMAN, George. Ante el tiempo: Historia del arte y anacronismo de las imágenes. Buenos Aires: Adriana Hidalgo, 2006.

FORD, Andrew. Epic as Genre. In: BLOOM, Harold (ed.). Homer. New York: Chelsea House, 2007.

GALVÃO, Duarte. Chronica de El-Rei D. Affonso Henriques. Lisboa: Escriptorio, 1906. HANSEN, João Adolfo. Notas sobre o gênero épico. In: TEIXEIRA, Ivan (org.). Épicos. São Paulo: Imprensa Oficial do Estado de São Paulo, 2008b. (Multiclássicos).

HOMERO. Ilíada. Tradução: Frederico Lourenço. São Paulo: Penguim Classics, Companhia das letras, 2014.

HOMERO. Odisseia. Tradução e introdução: Frederico Lourenço. São Paulo: Penguin Classics, Companhia das Letras, 2014.

HORÁCIO. Arte Poética. Tradução e introdução: R. M. Rosado Fernandes. Lisboa: Editorial Inquérito Limitada, 1984.

LOURENÇO, Eduardo. Portugal como destino. Lisboa: Gradiva, 1999. 


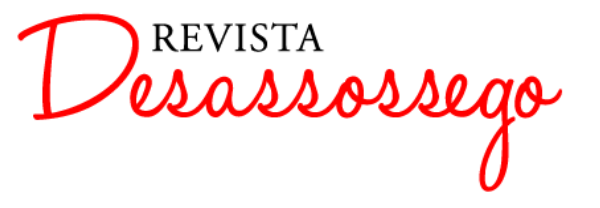

DESASSOSSEGO 20 | DEZ/2018 | ISSN 2175-3180 DOI: http://dx.doi.org/10.11606/issn.2175-3180.v10i20p5-21

MATOS, Maria Vitalina Leal de. Lusíadas (OS). In: SILVA, Vitor Aguiar e (coord.).

Dicionário de Luís de Camões. São Paulo: Leya, 2011.

OSÓRIO, D. Jerônimo. Da ensinança e educação do Rei. Tradução: A. Guimarães Pinto. Lisboa: Imprensa Nacional-Casa da Moeda, 2005.

QUINTILIANO. Instituição Oratória. Tomo I. Tradução: Bruno Fregni Bassetto. Campinas: Editora da Unicamp, 2015.

QUINTILIANO. Instituição Oratória. Tomo IV. Tradução: Bruno Fregbi Bassetto. Campinas: Editora da Unicamp, 2016.

RODRIGUES, José Maria. Estudos sobre os Lusíadas. Rio de Janeiro: Academia Brasileira de Letras, 2010.

SILVA, Luís de Oliveira e. Épica e Guerra. Revista da Faculdade de Ciências Sociais e Humanas. Lisboa, n. 16, p. 69-89, 2003.

VIRGÍlLIO. Eneida. Tradução: Carlos Alberto Nunes. São Paulo: Editora 34, 2014. 